\title{
QUEEN'S
UNIVERSITY
BELFAST
}

\section{Dendritic receptors designed to bind polyanions in both organic and aqueous media}

Hardy, J. G., Ashworth, I., Brennan, C., \& Smith, D. K. (2007). Dendritic receptors designed to bind polyanions in both organic and aqueous media. Organic \& biomolecular chemistry, 5(6), 900-906.

https://doi.org/10.1039/b618063a

\section{Published in:}

Organic \& biomolecular chemistry

\section{Document Version:}

Peer reviewed version

Queen's University Belfast - Research Portal:

Link to publication record in Queen's University Belfast Research Portal

\section{Publisher rights}

(c) The Royal Society of Chemistry 2007.

\section{General rights}

Copyright for the publications made accessible via the Queen's University Belfast Research Portal is retained by the author(s) and / or other copyright owners and it is a condition of accessing these publications that users recognise and abide by the legal requirements associated with these rights.

Take down policy

The Research Portal is Queen's institutional repository that provides access to Queen's research output. Every effort has been made to ensure that content in the Research Portal does not infringe any person's rights, or applicable UK laws. If you discover content in the Research Portal that you believe breaches copyright or violates any law, please contact openaccess@qub.ac.uk. 
Dendritic receptors designed to bind polyanions in both organic and aqueous media

John G. Hardy ${ }^{a}$, lan Ashworth ${ }^{b}$, Colin Brennan ${ }^{b}$ and David K. Smith *a

aDepartment of Chemistry, University of York, York, UK YO10 5DD. E-mail: dks3@york.ac.uk;

Fax: +44 (0)1904 432 516; Tel: +44 (0)1904 434181

${ }^{\mathrm{b}}$ Technology and Projects Department, Syngenta, Huddersfield, UK HD2 1FF

Received 11th December 2006 , Accepted 26th January 2007

First published on the web 7th February 2007

This paper reports the synthesis of dendrons containing a spermine unit at their focal point. The dendritic branching is based on L-lysine building blocks, and has terminal oligo(ethyleneglycol) units on the surface. As a consequence of the solubilising surface groups, these dendrons have high solubility in solvents with widely different polarities (e.g., dichloromethane and water). The protonated spermine unit at the focal point is an effective anion binding fragment and, as such, these dendrons are able to bind to polyanions. This paper demonstrates that polyanions can be bound in both dichloromethane (using a dye solubilisation assay) and in water (competitive ATP binding assay). In organic media the dendritic branching appears to have a pro-active effect on the solubilisation of the dye, with more dye being solubilised by higher generations of dendron. On the other hand, in water the degree of branching has no impact on the anion binding process. We propose that in this case, the spermine unit is effectively solvated by the bulk solvent and the dendritic branching does not need to play an active role in assisting solubility. Dendritic effects on anion binding have therefore been elucidated in different solvents. The dendritic branching plays a pro-active role in providing the anion binding unit with good solubility in apolar solvent media.

\section{Introduction}


Dendrimers and dendrons make a vital contribution to the field of nanochemistry as a consequence of their unique structural features..$^{1}$ In particular, the inherent branched structures of dendritic molecules can be exploited in the field of molecular recognition to

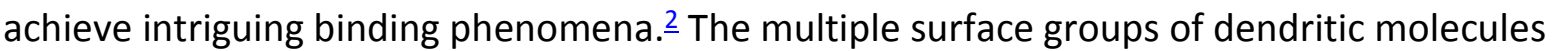
are able to amplify binding strengths by multivalency phenomena. $\frac{3}{\text { On }}$ the other hand, binding at the encapsulated core (or focal point) of a dendritic structure takes place in a unique micro-environment, which can have a direct impact on the binding event. $\stackrel{4}{-}$ This mimics the way in which the three-dimensional peptidic architecture places the active site of an enzyme in a well-defined local environment. $\underline{5}$

Over recent years, anion binding has developed into a key area of supramolecular chemistry, $\underline{\underline{6}}$ as a consequence of the wide-ranging importance of anions in environmental and biological processes. Whilst binding anions in organic solvents is relatively widespread, anion binding in water is less common and requires specific solutions. The most successful strategies involve the use of transition metal based receptors,,- which bind anions through dative bond formation, or protonated polyamines,, which bind anions using a combination of electrostatics and hydrogen bonding.

Perhaps surprisingly, dendritic receptors for anions remain relatively unexplored. Dendrimers with metallocene-functionalised surfaces have been investigated by the groups of Astruc and Kaifer. $\underline{9}$ These multivalent anion receptors were demonstrated to be capable of binding multiple anions in organic media, and exhibited dendritic amplification of their ability to electrochemically sense the anionic target. We used a similar anion binding strategy within a dendrimer, only located the metallocene unit at the core, rather than on the surface. We demonstrated that in this case, the branching inhibited the magnitude of electrochemical response to halide anions. ${ }^{10}$ Vögtle and co-workers prepared polyvalent dendritic ureas, which were able to extract multiple oxo-anions from water into an organic phase. $\underline{\underline{11}}$ The groups of van Koten and Stoddart prepared dendrimers with internal quaternised amines, which were able to bind anions in organic media. $\underline{12}$ They used anionic dyes to demonstrate that binding had taken place. There have also been a number of studies of dendrimers containing multiple protonated amines which have been shown to effectively internalise anionic $\underline{\text { dyes }} \cdot \underline{13}$

As part of a wider program investigating supramolecular dendrimer chemistry, $\underline{14}$ we recently employed spermine groups on the surface of dendrons, in order to achieve ultra 
high-affinity DNA binding in water..$\underline{15}$ Spermine is a simple polyamine used extensively by biological systems as a nucleic acid binder. $\underline{16}$ Protonated polyamines such as spermine, although good anion receptors in aqueous media, are usually ineffective in apolar media due to their poor solubility. We became interested in employing spermine at the focal point of a dendron. We reasoned that with an appropriate choice of dendritic framework, we could generate highly soluble spermine derivatives, which would operate in solvent media with widely different polarities - for example, both water and organic media. This paper reports the results of our initial investigations into this anion binding strategy.

\section{Results and discussion}

\section{Synthesis}

We targeted first and second generation L-lysine based dendritic structures $\mathbf{G 1}$ and $\mathbf{G 2}$, and model system G0, each of which has an anion binding spermine unit at the focal point and oligo ethylene oxide surface group(s) (ㄷheme 1). We chose these surface groups because they provide solubility across a broad range of solvents and furthermore, do not have any innate affinity for anions. It is worth noting that the dendrons are wholly constructed from biocompatible building blocks. 


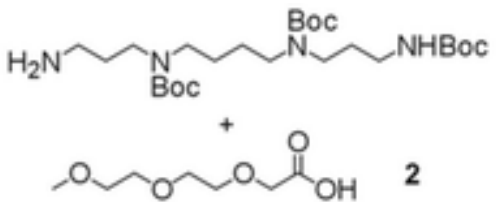

ZHN

$\sum_{\mathrm{ZHN}} \mathrm{OH}_{\mathrm{OH}}+1$

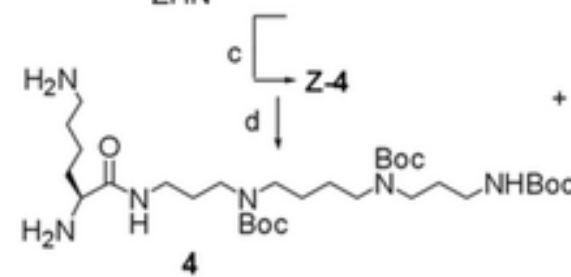

4

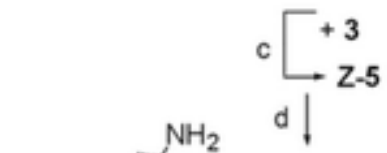

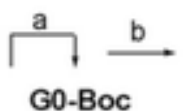

GO-Boc

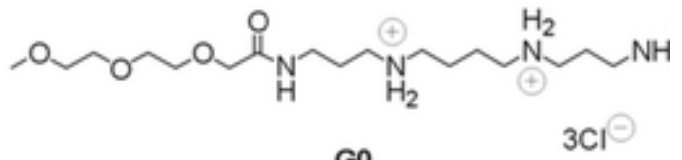

G0

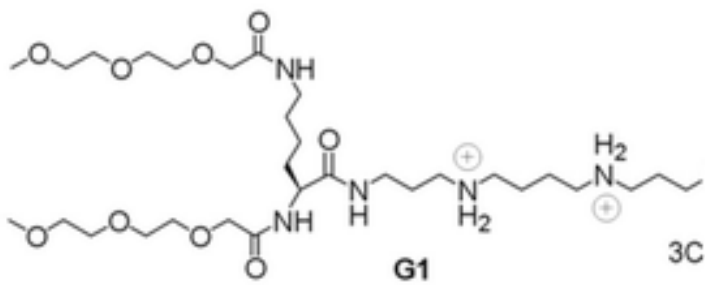

$3 \mathrm{C}$
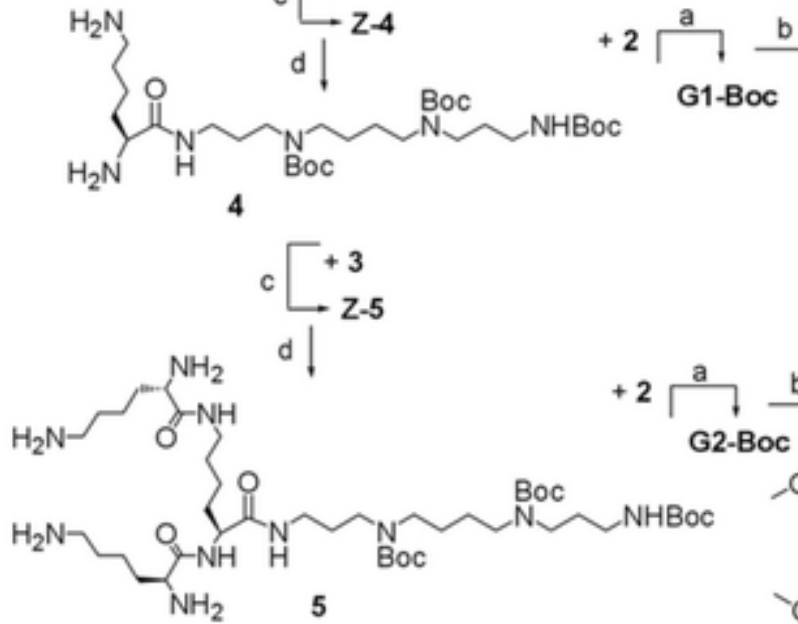

G1-Boc<smiles>CNC(=O)C(N)CCCCNC(=O)COCCOCCOC</smiles>

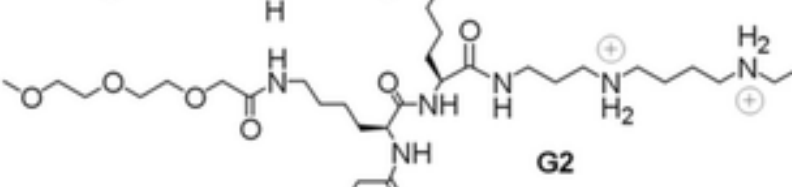

Scheme 1 Synthesis of dendritic anion

binders G0, G1 and G2. (a) DCC, $\underline{\mathrm{HOBt}}, \mathrm{Et}_{3} \mathrm{~N}$,

$\underline{\mathrm{DCM}}$; (b) $\mathrm{HCl}_{(\mathrm{g})}, \underline{\mathrm{MeOH}}$; (c) DCC, $\underline{\mathrm{HOBt}}, \mathrm{Et}_{3} \mathrm{~N}$,

$\underline{\mathrm{DCM}}$; (d) $\mathrm{Pd}(\mathrm{OH})_{2} / \mathrm{C}, \mathrm{HCOONH}_{4}$, $\underline{\mathrm{EtOH}}$.

The synthesis of these dendrons was achieved using a divergent strategy (Scheme 1). To synthesise non-dendritic control receptor $\mathbf{G 0}$, tri-Boc protected spermine $\mathbf{1}$ was made according to a methodology published by the Blagbrough group, $\underline{\underline{17}}$ and coupled to $\underline{2-(2-(2-)}$ methoxyethoxy)ethoxy)acetic acid (2) using DCC and $\underline{\mathrm{HOBt}}$ to yield G0-Boc. The Boc protecting groups were subsequently removed from the spermine unit using $\mathrm{HCl}$ gas in $\underline{\text { methanol }}$ to provide $\mathbf{G 0}$. To synthesise G1, Z-protected lysine $\mathbf{3}$ was coupled with protected spermine 1 using DCC methodology to yield compound Z-4. Removal of the Z protecting groups from the product with palladium hydroxide on carbon and ammonium formate gave key intermediate $\mathbf{4}$. Coupling of $\mathbf{4}$ with acid $\mathbf{2}$ gave compound G1-Boc, and subsequent removal of the Boc groups with $\mathrm{HCl}$ gas in methanol provided receptor $\mathbf{G 1}$ in a good overall 
yield of $41 \%$ (four steps). To synthesise $\mathbf{G 2}$, intermediate $\mathbf{4}$ was coupled with Z-protected lysine 3 to give compound Z-5. The product had the Z protecting groups removed using $\mathrm{Pd}(\mathrm{OH})_{2}$ and ammonium formate to give compound $\mathbf{5}$. Coupling compound $\mathbf{5}$ with acid $\mathbf{2}$ gave compound G2-Boc, which subsequently had the Boc protecting groups removed using $\mathrm{HCl}$ in methanol. This sequence gave receptor $\mathbf{G 2}$ in a good overall yield of $27 \%$ (six steps) from commercially available starting materials. The compounds were characterised using all the usual spectroscopic methods, and full data can be found in the Experimental section.

\section{Anion binding in organic media}

We developed assays to probe the potential of these receptors in both organic and aqueous media. In common with other studies of anion binding in organic media which use dendritic hosts, $\underline{12}$ we decided to use a dye solubilisation assay to probe the affinity of these hosts for anions.

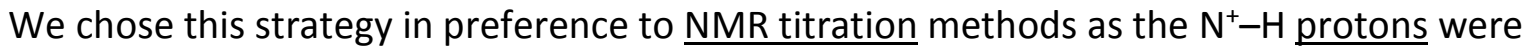
not readily observed and the other protons in the receptor did not give rise to significant shifts. This is partly a consequence of the fact that the protonated spermine unit in these receptors already has chloride counteranions associated with it, and consequently all anion binding experiments are effectively competition experiments. We therefore decided to use a highly charged anionic guest in order to maximise the binding interaction. However, as highly charged anions are not soluble in organic media, it was necessary to employ a solubilisation assay approach.

Aurin tricarboxylic acid is a powerful inhibitor of cellular processes that are dependent on the formation of protein nucleic acid complexes, $\underline{\underline{18}}$ and is commercially available as the tricarboxylate anion (Fig. 1). This polyanion is soluble in water, but not in organic media such as dichloromethane $(\underline{D C M})$. Our receptors have good solubility in $\underline{D C M}$ as a consequence of the oligo-ether surface groups. We therefore decided to probe the ability of our receptors to solubilise aurin tricarboxylate into this apolar solvent. 


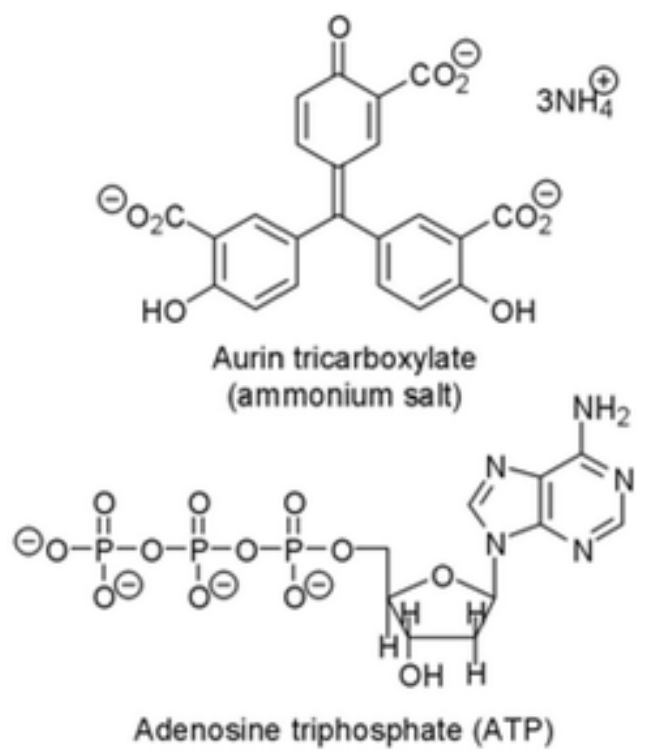

Fig. 1 Structures of anions investigated in this paper.

Solid aurin tricarboxylate (as its tri-ammonium salt) was suspended in a $1 \mathrm{mM}$ solution of the anion receptor (dissolved in $\underline{\mathrm{DCM}}$ ) and stirred for $24 \mathrm{~h} . \underline{19}$ The mixture was then filtered to remove excess $\underline{d y e}$, and the solution analysed by $\underline{\text { UV-Vis }} \underline{\text { spectrometry. Fig. } 2}$ provides a visual assessment of the degree of $\underline{\text { dye }}$ solubilisation in each case and a quantitative measure is given in Table 1 (normalised with respect to the solubilisation caused by G0). In the absence of receptor, effectively no dye was solubilised into $\underline{\mathrm{DCM}}$; however, in the presence of the receptors solubilisation occurred. The extent of solubilisation increased in the order $\mathbf{G 0}<\mathbf{G 1}<\mathbf{G 2}$. There is, therefore, a clear dendritic effect on the uptake of the anionic dye into organic solvent.

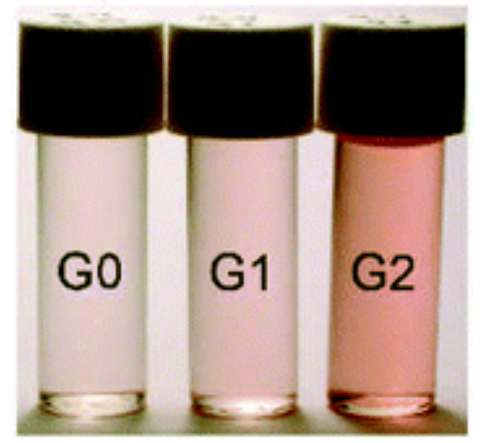

Fig. 2 Solutions resulting from the solubilisation study performed with G0, G1 
and $\mathbf{G 2}$ (each $1 \mathrm{mM}$ ) in dichloromethane

solution with aurin tricarboxylate

(ammonium salt).

Table 1 Solubilisation of aurin tricarboxylate into dichloromethane as assessed by UV-Vis spectrometry using absorption at $\lambda_{\max }(522 \mathrm{~nm})$ and normalised relative to the uptake exhibited by compound $\mathbf{G 0}$
Host
Degree of solubilisation

None (DCM alone)

0.02

G0

1.00

G1

1.81

G2

3.64

We have previously demonstrated that interactions between protonated amines and carboxylate anions play an essential role in the solubilisation of aurin-based dyes by dendritic systems. $\frac{19 \mathrm{~b}}{}$ We propose that in this case, the dendritic effect is a consequence of the dendritic branching, which is compatible with organic solvents such as DCM. Indeed, without the presence of this dendritic branching, the highly charged spermine unit would not be soluble in the solvent $(\underline{D C M})$ in the first place, as protonated spermine is not compatible with low-polarity media. Consequently, the ability of the dendritic branching to interact favourably with the solvent enhances the solubility of the overall complex and thus higher generation systems are better able to solubilise the dye.

There is also the possibility of secondary interactions between the anionic dye and hydrogen bonding amide groups in the dendritic branching, which will enhance the degree of uptake-such interactions are well-known in the literature..$^{20}$

Furthermore, it should be noted that the ether units in the dendritic branches may interact with the $\mathrm{NH}_{4}{ }^{+}$cation and further enhance the solubilisation process. However, these ether units also have the potential to interact with the protonated spermine unit at the focal point of the dendron itself, and so we do not believe that ether $-\mathrm{NH}_{4}{ }^{+}$interactions provide the main driving force behind the solubilisation event. 


\section{Anion binding in water}

We then decided to determine whether our receptors would operate in aqueous solution. We chose to probe the interaction between our polyanionic receptors and adenosine triphosphate (ATP), a biologically-relevant phosphate polyanion. In 1977, Nakai and Glinsmann developed a simple and innovative competition assay to determine the binding between protonated amines and ATP and we applied their methodology in this study. $\underline{\underline{21}}$ Their method involves placing a constant amount of ATP and cationic resin (Dowex AG1-X2) in tris-chloride buffered water $(\mathrm{pH}$ 7.5). Various amounts of soluble receptor are then added. The receptor competes with the solid cationic resin for binding the ATP, and the residual amount of ATP in the solution, which can be determined by UV-Vis spectrometry, reflects the affinity of the receptor for ATP. The Igarashi group have since published minor modifications to handling the data from this procedure. $\underline{22}$ We applied both data-handling approaches to investigate ATP binding in water at $\mathrm{pH} 7$, and for the purposes of comparison also determined the binding of spermine and spermidine ( $\underline{\text { Fig. } 3}$ ) to the target anion.

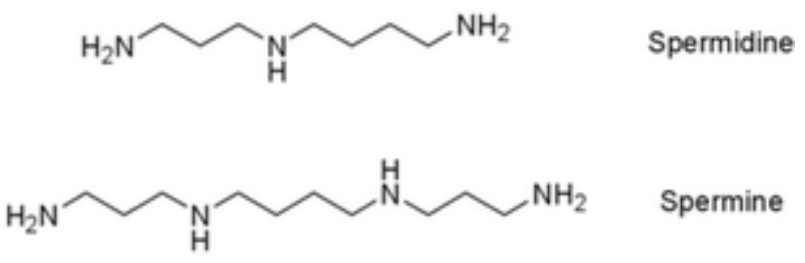

Fig. 3 Structures of spermidine and spermine.

Importantly, the binding constants for spermine and spermidine, generated using the assumption of $1: 1$ binding with the polyanion, were in good agreement with the data in the literature, validating our use of the assay (Table 2). We then investigated the performance of receptors $\mathbf{G 0 - G 2}$ in this assay. It is clear from the data that receptors $\mathbf{G 0}$, G1 and $\mathbf{G 2}$ show very similar affinities for ATP as spermidine. Although our receptors contain four nitrogen atoms, they are actually more similar to spermidine than spermine, as one of the four nitrogen atoms has been converted to an amide and thus cannot be protonated. Therefore the similarity in behaviour to spermidine is to be expected. 
Table 2 Log $K$ values determined for ATP binding with the receptors at $\mathrm{pH} 7$ in tris-buffered water using competitive binding assay and assuming a $1: 1$ binding model using methods from ref. 21 and $\underline{22}$

\begin{tabular}{lll} 
Host & Log $\boldsymbol{K}^{\mathbf{2 1}}$ & $\log \boldsymbol{K}^{\mathbf{2 2}}$ \\
\hline Spermine & 4.06 & 3.76 \\
Spermidine & 3.08 & 3.22 \\
G0 & 2.80 & 3.28 \\
G1 & 2.74 & 3.28 \\
G2 & 2.82 & 3.37 \\
\hline
\end{tabular}

Furthermore, it is clear that receptors G0-G2 all give similar degrees of binding, irrespective of the extent of functionalisation. This indicates that the dendritic branching does not inhibit the ability of the polyamine unit at the focal point to bind ATP anions in

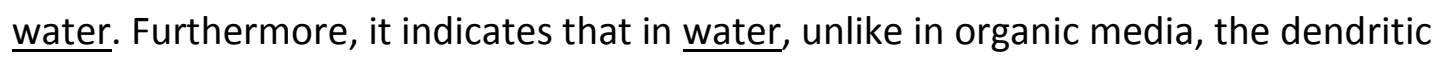
branching does not assist the anion binding process. In aqueous solution, the polar dendron structure and the spermine binding unit will both be heavily solvated, and we propose it is therefore unable to generate a specific microenvironment at the core. In addition, the affinity of neutral amides for anions is limited in polar media, and there will be no additional anion binding within the dendritic framework. For this reason, we argue there is no dendritic effect in water and the binding afforded by the protonated (solvated) polyamine unit is unaffected by dendritic functionalisation.

\section{Conclusions}

In summary, we have demonstrated that these new dendritic structures enable anion binding to be achieved by the same receptor in solvent media with large difference in polarities ( $\underline{\mathrm{DCM}}, \varepsilon=9.1, \underline{\mathrm{H}_{2} \mathrm{O}}, \varepsilon=80$ ). The dendritic branching plays a pro-active role in enhancing the solubility of the system in apolar media. The dendritic structure has a direct impact on the binding in organic media where it can help ensure the charged spermine unit and its charged guest remain compatible with the surrounding apolar solvent. The 
more extensive the dendritic branching, the more able it is to solubilise the charged complex, and hence higher generation systems cause enhanced uptake of the dye-a 'dendritic effect'. $\underline{23}$ However, there is no dendritic effect in water, where the whole structure will be largely solvated and the branching will have less impact on the charged binding unit. We propose that these systems, which are compatible with a broad range of solvent systems may have future potential as anion transport agents. Furthermore, the incorporation of additional functionality into the dendritic structures may enable the development of medically-relevant anion complexation agents.

\section{Experimental}

\section{Materials and methods}

Silica column chromatography was carried out using silica gel provided by Fluorochem Ltd. (35-70 $\mu$ ). Thin layer chromatography was performed on commercially available Merck aluminium backed silica plates. Preparative gel permeation chromatography was carried out using a 2 m glass column packed with Biobeads SX-1 supplied by Biorad, or a shorter length column $(0.5 \mathrm{~m})$ packed with Sephadex LH-20. Proton and carbon NMR spectra were recorded on a Jeol 400 spectrometer $\left({ }^{1} \mathrm{H} 400 \mathrm{MHz},{ }^{13} \mathrm{C} 100 \mathrm{MHz}\right)$. Samples were recorded as solutions in $\underline{\mathrm{CDCl}_{3}}$ and chemical shifts $(\delta)$ are quoted in parts per million, referenced to residual solvent. Coupling constant values $(J)$ are given in $\mathrm{Hz}$. DEPT experiments were used to assist in the assignment of ${ }^{13} \mathrm{C}$ NMR spectra. Melting points were measured on an Electrothermal IA 9100 digital melting point apparatus and are uncorrected. Positive ion electrospray mass spectra were recorded on a Finnigan LCQ mass spectrometer. Positive ion fast atom bombardment mass spectra were recorded on a Fisons Instruments Autospec mass spectrometer, with $\underline{3-n i t r o b e n z y l ~ a l c o h o l ~ a s ~ m a t r i x . ~ P o l y e t h y l e n e ~ g l y c o l s ~}$ and/or polyethylene glycol mono-methyl ethers were used as calibrants for HRMS determinations. The isotope distribution observed for mass spectral ions of the larger molecules is consistent with data calculated from isotopic abundances. Infra-red spectra were recorded using an ATI Mattson Genesis Series FTIR spectrometer.

Compound 1 was synthesised according to the methodology previously published by Blagbrough and co-workers. $\stackrel{17}{ }$ Compounds $\mathbf{2}$ and $\mathbf{3}$ were commercially available. The full 
synthetic methodology and characterisaton data for $\mathbf{G 0}$ can be found in the supplementary information of our previous publication. $\underline{15 a}$

\section{Synthesis and characterisation}

Compound Z-4. Compound 1 (4.0 g, 8.75 mmol, 1.1 eq.) and compound 3 ( $3.63 \mathrm{~g}, 8 \mathrm{mmol}$, 1 eq.) were dissolved in EtOAc (100 mL). DCC (2.48 g, $12 \mathrm{mmol}, 1.5$ eq.), HOBt $(1.62 \mathrm{~g}, 12$ mmol, 1.5 eq.) and $\mathrm{Et}_{3} \mathrm{~N}(1.21 \mathrm{~g}, 12 \mathrm{mmol}, 1.5$ eq.) were added and the mixture was placed in an ice bath for $1 \mathrm{~h}$ and then left to stir at rt for $2 \mathrm{~d}$. Dicyclohexylurea (DCU) was removed by filtration, and the solvents removed by rotary evaporation. The crude product was purified by silica column chromatography (70:30 cyclohexane-EtOAc), a white solid was recovered $(5.56 \mathrm{~g}, 62 \%) . \underline{{ }^{1} \mathrm{H} N M R}\left(\mathrm{CD}_{3} \mathrm{OD}, 400 \mathrm{MHz}\right) \delta_{\mathrm{H}} 7.28-7.13(10 \mathrm{H}, \mathrm{m}, \mathrm{CH}$ aromatic), 6.98-6.87 (1H, br m, NH amide), 6.54-6.39 (3H, br m, NHBOC, NHZ), 4.97 (2H, s, $\left.\mathrm{OCH}_{2} \mathrm{Ph}\right), 4.94\left(2 \mathrm{H}, \mathrm{s}, \mathrm{OCH}_{2} \mathrm{Ph}\right), 3.90(1 \mathrm{H}, \mathrm{dd}, J=5.2,8.9 \mathrm{~Hz}, \mathrm{COCH}(\mathrm{R}) \mathrm{NH}), 3.28-3.14(14 \mathrm{H}$, br m, $\left.\mathrm{CH}_{2} \mathrm{~N}\right), 3.11\left(2 \mathrm{H}, \mathrm{t}, J=6.6 \mathrm{~Hz}, \mathrm{CH}_{2} \mathrm{~N}\right), 3.01\left(2 \mathrm{H}, \mathrm{t}, J=7.3 \mathrm{~Hz}, \mathrm{CH}_{2} \mathrm{~N}\right), 1.71-1.53(4 \mathrm{H}, b r$

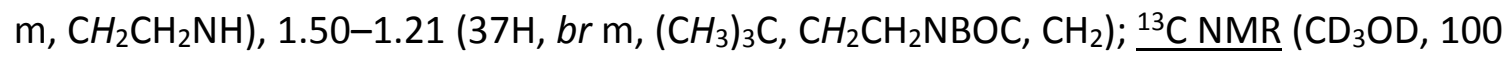
$\mathrm{MHz}) \delta_{\mathrm{c}} 175.12$ (CONH, amide) $, 158.92,158.41,157.78$ (CONBoc $\times 2$, CONHBoc, CONHZ $\times$ 2, overlapping), 138.43, 138.15, 129.47, 129.44, 128.75 ( $\mathrm{Ar}-\mathrm{C}$, overlapping), 80.92, 79.93 $\left(\mathrm{C}\left(\mathrm{CH}_{3}\right)_{3} \times 3\right.$, overlapping), 67.67, $67.31\left(\mathrm{CH}_{2}\right.$ benzylic), $56.01(\mathrm{COCH}(\mathrm{R}) \mathrm{NH}), 46.56,46.37$, $41.81,40.66,38.23,37.61,37.30,30.46\left(\mathrm{CH}_{2}\right.$, overlapping), $28.78\left(\left(\mathrm{CH}_{3}\right)_{3} \mathrm{C} \times 9\right.$, overlapping), 27.64, 25.41, $24.09\left(\mathrm{CH}_{2} \mathrm{CH}_{2} \mathrm{~N}\right.$, overlapping); $\underline{\mathbb{R}}(\mathrm{KBr} \operatorname{disc}) v_{\max } \mathrm{cm}^{-1} 3444$, $3336(\mathrm{NH}), 1600(\mathrm{C}=\mathrm{O}), 1639(\mathrm{C}=\mathrm{O}), 1600(\mathrm{C}=0), 1580,1552$ (CONH, amide 2), 1509, 1251 (OCONH carbamate); $\underline{\text { ESI-MS }}\left(\mathrm{m} / \mathrm{z}\right.$ ) calculated value for $\mathrm{C}_{47} \mathrm{H}_{74} \mathrm{~N}_{6} \mathrm{O}_{11}$ 898.5: (ES ${ }^{+}$) found $921.4\left([\mathrm{M}+\mathrm{Na}]^{+}, 100 \%\right) ; \mathrm{HR}-\mathrm{FAB}$ calculated value for $\mathrm{C}_{47} \mathrm{H}_{74} \mathrm{~N}_{6} \mathrm{O}_{11} \mathrm{Na}$ 921.5313: found 921.5316; $R_{\mathrm{f}} 0.13$ (70 : 30 EtOAC- $\underline{\text { hexane, }}$ ninhydrin stain); m.p. $52-54{ }^{\circ} \mathrm{C} ;[\alpha]^{293} \mathrm{D}-5.1(\mathrm{c}=$ 1.0, $\left.\mathrm{CH}_{3} \mathrm{OH}\right)$.

Compound 4. Compound Z-4 (5.0 g, 5.5 mmol, 1 eq.), ammonium formate ( $1.0 \mathrm{~g}, 16.5$ mmol, 3 eq.) and palladium hydroxide on carbon ( $20 \mathrm{wt} \%$, wet) $(0.35 \mathrm{~g}, 2.75 \mathrm{mmol}, 0.5$ eq.) were refluxed in ethanol $(100 \mathrm{~mL})$ for $48 \mathrm{~h}$. The mixture was allowed to cool to room temperature and filtered over celite to remove the solids, and the solvents were removed on a rotary evaporator. The mixture was dissolved in $\underline{\mathrm{DCM}}(50 \mathrm{~mL})$, washed with conc. $\mathrm{NH}_{4} \mathrm{OH}$ and brine, dried over $\mathrm{MgSO}_{4}$, and the solvents removed on a rotary evaporator. $\mathrm{A}$ 
light yellow viscous oil was recovered (3.05 g, 88\%). ${ }^{1} \mathrm{H}$ NMR $\left(\mathrm{CD}_{3} \mathrm{OD}, 400 \mathrm{MHz}\right) \delta_{\mathrm{H}} 6.71-$ $6.69(1 \mathrm{H}, b r \mathrm{~m}, \mathrm{NH}$ amide $), 5.62-5.60(1 \mathrm{H}, b r \mathrm{~m}, \mathrm{NHBOC}), 3.60(1 \mathrm{H}, \mathrm{dd}, J=5.2,8.9 \mathrm{~Hz}$, $\mathrm{COCH}(\mathrm{R}) \mathrm{NH}), 3.29-3.15\left(10 \mathrm{H}, \mathrm{br} \mathrm{m}, \mathrm{CH}_{2} \mathrm{~N}\right), 3.16\left(2 \mathrm{H}, \mathrm{t}, J=6.6 \mathrm{~Hz}, \mathrm{CH}_{2} \mathrm{NH}\right), 2.73(2 \mathrm{H}, \mathrm{t}, J=$ $\left.7.3 \mathrm{~Hz}, \mathrm{CH}_{2} \mathrm{NH}_{2}\right), 1.71-1.53\left(4 \mathrm{H}, \mathrm{br} \mathrm{m}, \mathrm{CH}_{2} \mathrm{CH}_{2} \mathrm{~N}\right), 1.50-1.21\left(37 \mathrm{H}, \mathrm{br} \mathrm{m},\left(\mathrm{CH}_{3}\right)_{3} \mathrm{C}\right.$, $\left.\mathrm{CH}_{2} \mathrm{CH}_{2} \mathrm{NBoc}, \mathrm{CH}_{2}\right) ;{ }^{13} \mathrm{C} \mathrm{NMR}\left(\mathrm{CD}_{3} \mathrm{OD}, 100 \mathrm{MHz}\right) \delta_{\mathrm{C}} 177.03$ (CONH, amide), 157.60, 155.63

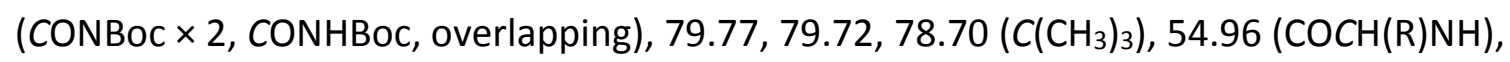
$47.76,47.55,44.313,41.04,37.56,35.32$, 34.92, 32.30, $\left(\mathrm{CH}_{2}\right.$, overlapping), $27.45\left(\left(\mathrm{CH}_{3}\right)_{3} \mathrm{C}\right.$ $\times$ 9, overlapping), 25.65, $22.72\left(\mathrm{CH}_{2} \mathrm{CH}_{2} \mathrm{~N}\right.$, overlapping); $\underline{\mathrm{R}}(\mathrm{KBr} \operatorname{disc}) v_{\max } \mathrm{cm}^{-1} 3443,3336$ (NH), 1638 (C=O), 1553 (CONH, amide 2), 1509, 1251 (OCONH carbamate); ESI-MS $(\mathrm{m} / \mathrm{z}$ ) calculated value for $\mathrm{C}_{31} \mathrm{H}_{62} \mathrm{~N}_{6} \mathrm{O}_{7} 630$ : $\left(\mathrm{ES}^{+}\right)$found $653\left([\mathrm{M}+\mathrm{Na}]^{+}, 100 \%\right)$. HR-FAB calculated value for $\mathrm{C}_{31} \mathrm{H}_{62} \mathrm{~N}_{6} \mathrm{O}_{7} \mathrm{Na}$ 653.4578: found 653.4568.

Compound G1-Boc. Compound 4 (0.30 g, 0.6 mmol, 1 eq.) and carboxylic acid 2 (0.24 g, $0.2 \mathrm{~mL}, 1.32 \mathrm{mmol}, 2.2$ eq.) were dissolved in DCM $(75 \mathrm{~mL})$. DCC (0.30 g, $1.5 \mathrm{mmol}, 2.5$ eq.), $\underline{\mathrm{HOBt}}\left(0.202 \mathrm{~g}, 1.5 \mathrm{mmol}, 2.5\right.$ eq.) and $\mathrm{Et}_{3} \mathrm{~N}$ (0.15 g, $1.5 \mathrm{mmol}, 2.5$ eq.) were added and the mixture was placed in an ice bath for $1 \mathrm{~h}$ and then left to stir at $\mathrm{rt}$ for $2 \mathrm{~d}$. Dicyclohexylurea (DCU) was removed by filtration, and the solvents removed by rotary evaporation. The crude product was purified by preparative gel permeation chromatography ( $\underline{\mathrm{MeOH}}$, Sephadex), a clear oil was recovered $(0.42 \mathrm{~g}, 0.45 \mathrm{mmol}, 75 \%)$. $\underline{{ }^{1} \mathrm{H} \mathrm{NMR}}\left(\mathrm{CD}_{3} \mathrm{OD}, 400 \mathrm{MHz}\right) \delta_{\mathrm{H}} 7.99-7.83(2 \mathrm{H}, b r \mathrm{~m}, \mathrm{NH}$ amide $), 7.06-7.02(1 \mathrm{H}, b r \mathrm{~m}, \mathrm{NH}$ amide), 6.46-6.36 (1H, br m, NHBOC), $4.23(1 \mathrm{H}, \mathrm{dd}, J=5.2,8.9 \mathrm{~Hz}, \mathrm{COCH}(\mathrm{R}) \mathrm{NH}), 4.01-3.89$ $\left(4 \mathrm{H}, b r \mathrm{~s}, \mathrm{OCH}_{2} \mathrm{CONH}\right), 3.80-3.40\left(16 \mathrm{H}, b r \mathrm{~m}, \mathrm{OCH}_{2}\right), 3.35-3.30\left(6 \mathrm{H}, b r \mathrm{~s}, \mathrm{OCH}_{3}\right), 3.28-3.14$ $\left(10 \mathrm{H}, b r \mathrm{~m}, \mathrm{CH}_{2} \mathrm{~N}\right), 3.13-3.09\left(2 \mathrm{H}, \mathrm{t}, J=6.6 \mathrm{~Hz}, \mathrm{CH}_{2} \mathrm{NH}\right), 3.06-2.95(2 \mathrm{H}, \mathrm{t}, J=7.3 \mathrm{~Hz}$, $\left.\mathrm{CH}_{2} \mathrm{NH}\right), 1.71-1.53\left(4 \mathrm{H}\right.$, br m, $\left.\mathrm{CH}_{2} \mathrm{CH}_{2} \mathrm{~N}\right), 1.52-1.22\left(37 \mathrm{H}\right.$, br m, $\left.\left(\mathrm{CH}_{3}\right)_{3} \mathrm{C}, \mathrm{CH}_{2} \mathrm{CH}_{2} \mathrm{~N}, \mathrm{CH}_{2}\right) ;{ }^{13} \mathrm{C}$ $\underline{\mathrm{NMR}}\left(\mathrm{CD}_{3} \mathrm{OD}, 100 \mathrm{MHz}\right) \delta_{\mathrm{C}} 173.78,172.60$ (CONH $\times$ 3, amide, overlapping), 158.92, 157.78

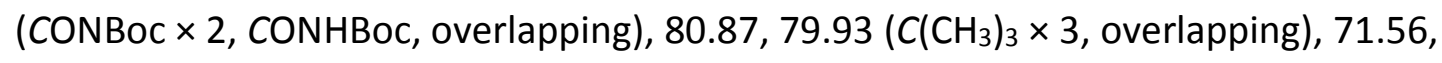
71.37, 71.36, 71.34, $71.28\left(\mathrm{CH}_{2} \mathrm{O}\right.$, overlapping), $59.11\left(\mathrm{OCH}_{3}\right), 55.25(\mathrm{COCH}(\mathrm{R}) \mathrm{NH}), 46.56$, $46.37,41.81,40.66,38.23,37.61,37.30,30.08\left(\mathrm{CH}_{2}\right.$, overlapping), $28.78\left(\left(\mathrm{CH}_{3}\right)_{3} \mathrm{C} \times 9\right.$, overlapping), 27.64, 25.41, $24.32\left(\mathrm{CH}_{2} \mathrm{CH}_{2} \mathrm{~N}\right.$, overlapping); IR ( $\left.\mathrm{KBr} \operatorname{disc}\right) v_{\max } \mathrm{Cm}^{-1} 3444$, $3336(\mathrm{NH}), 1641$ ( $\mathrm{C}=\mathrm{O}), 1553$ (CONH, amide 2), 1509 (CONH, carbamate), 1366 (ether), 1251 (C-O, carbamate). ESI-MS $(m / z)$ calculated value for $\mathrm{C}_{45} \mathrm{H}_{86} \mathrm{~N}_{6} \mathrm{O}_{15} \mathrm{Na} 973.6$ (100.0\%), 
974.6 (50.2\%), 975.6 (16.5\%): (ES+) found 973.5 (100\%), 974.5 (48.2\%), 975.5 (12.4\%); $R_{\mathrm{f}}$

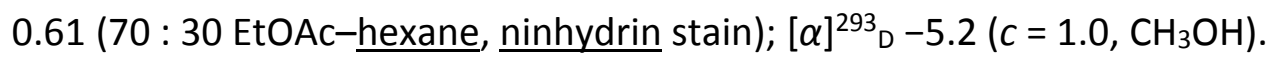

Anion receptor G1. Compound G1-Boc $(0.060 \mathrm{~g}, 0.79 \mathrm{mmol})$ was dissolved in $\mathrm{MeOH}(150$ $\mathrm{mL}$ ) and gaseous hydrogen chloride was bubbled through for 30 seconds. The reaction was allowed to stir for $2 \mathrm{~h}$, after which time the solvent was removed under reduced pressure, and a white solid was recovered $(0.39 \mathrm{~g}, 81 \%)$. Yield calculated for $\mathrm{HCl}$ salt, $\mathrm{FW}: 760 . \underline{\mathrm{H}}$ NMR $\left(\mathrm{CD}_{3} \mathrm{OD}, 400 \mathrm{MHz}\right) \delta_{\mathrm{H}} 7.99-7.83(2 \mathrm{H}, b r \mathrm{~m}, \mathrm{NH}$ amide $), 7.06-7.02(1 \mathrm{H}, b r \mathrm{~m}, \mathrm{NH}$ amide), $4.23(1 \mathrm{H}, \mathrm{dd}, J=5.3,8.9 \mathrm{~Hz}, \mathrm{COCH}(\mathrm{R}) \mathrm{NH}), 4.01-3.89\left(4 \mathrm{H}, b r \mathrm{~s}, \mathrm{OCH}_{2} \mathrm{CONH}\right), 3.70-$ $3.40\left(16 \mathrm{H}, b r \mathrm{~m}, \mathrm{OCH}_{2}\right), 3.35-3.30\left(6 \mathrm{H}, b r \mathrm{~s}, \mathrm{OCH}_{3}\right), 3.28-3.14\left(10 \mathrm{H}, b r \mathrm{~m}, \mathrm{CH}_{2} \mathrm{~N}\right), 3.15-2.93$

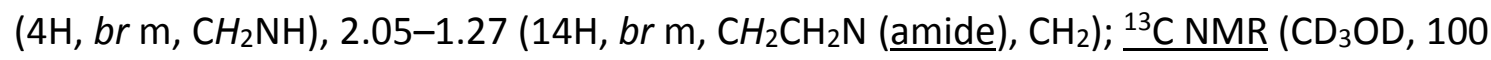
$\mathrm{MHz}) \delta_{\mathrm{c}} 174.25,174.19,173.96(\mathrm{CONH} \times 3), 73.07,71.56,71.03,\left(\mathrm{CH}_{2} \mathrm{O}\right.$, overlapping), $59.38\left(\mathrm{OCH}_{3}\right), 53.25(\mathrm{COCH}(\mathrm{R}) \mathrm{NH}), 39.34,37.61,37.30,32.03,30.32,28.38,24.50,24.45$ $\left(\mathrm{CH}_{2}\right.$, overlapping); $\underline{\mathrm{IR}}\left(\mathrm{KBr}\right.$ disc) $v_{\max } \mathrm{cm}^{-1} 3444,3336(\mathrm{NH}), 1641$ (C=O), 1604, 1553 (CONH, amide 2), 1366 (O- $\mathrm{CH}_{3}$, ether); ESI-MS $(\mathrm{m} / \mathrm{z})$ calculated value for $\mathrm{C}_{30} \mathrm{H}_{62} \mathrm{~N}_{6} \mathrm{O}_{9} \mathrm{Na} 673.5$ (100.0\%), 674.5 (33.5\%): (ES $\left.{ }^{+}\right)$found $673.5(100.0 \%), 674.5(30.5 \%) ;[\alpha]^{293}-5.3(c=1.0$, $\left.\mathrm{CH}_{3} \mathrm{OH}\right)$.

Compound Z-5. Compound 4 (1.25 g, 1.94 mmol, 1 eq.) and compound 3 (1.76 g, 4.26 $\mathrm{mmol}, 2.2$ eq.) were dissolved in DCM $(100 \mathrm{~mL})$. DCC (0.88 g, $4.26 \mathrm{mmol}, 2.2$ eq.), $\underline{\mathrm{HOBt}}$ ( $0.58 \mathrm{~g}, 4.26 \mathrm{mmol}, 2.2$ eq.) and $\mathrm{Et}_{3} \mathrm{~N}(0.43 \mathrm{~g}, 0.59 \mathrm{~mL}, 4.26 \mathrm{mmol}, 2.2$ eq.) were added and the mixture was placed in an ice bath for $1 \mathrm{~h}$ and then left to stir at $\mathrm{rt}$ for 2 days.

Dicyclohexylurea (DCU) was removed by filtration, and the solvents removed by rotary evaporation. The crude product was purified by preparative gel permeation chromatography (Biobeads, $90: 10 \underline{\mathrm{DCM}}-\underline{\mathrm{MeOH}}$ ), a tacky white solid was recovered (2.26

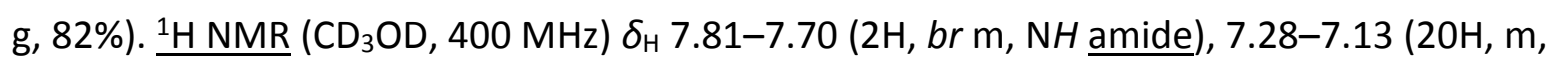
$\mathrm{CH}$ aromatic), 6.71-6.69 (1H, br m, NH amide $\mathrm{G1}), 6.63-6.33(5 \mathrm{H}, b r \mathrm{~m}, \mathrm{NHBOC}, \mathrm{NHZ})$, 5.05-4.92 (8H, m, OCH $2 \mathrm{Ph}), 4.25(1 \mathrm{H}, \mathrm{dd}, J=4.5,9.1 \mathrm{~Hz}, \mathrm{COCH}(\mathrm{R}) \mathrm{NH}), 4.09(1 \mathrm{H}, \mathrm{dd}, J=5.4$, $8.5 \mathrm{~Hz}, \mathrm{COCH}(\mathrm{R}) \mathrm{NH}), 4.00(1 \mathrm{H}, \mathrm{dd}, J=5.2,9.1 \mathrm{~Hz}, \mathrm{COCH}(\mathrm{R}) \mathrm{NH}, 1 \mathrm{H}), 3.28-3.14(16 \mathrm{H}, b r \mathrm{~m}$, $\left.\mathrm{CH}_{2} \mathrm{~N}\right), 3.01\left(2 \mathrm{H}, \mathrm{t}, \mathrm{J}=7.3 \mathrm{~Hz}, \mathrm{CH}_{2} \mathrm{NH}\right), 1.86-1.04\left(53 \mathrm{H}\right.$, br m, $\left.\mathrm{CH}_{2}, \mathrm{CH}_{3}\right) ;{ }^{13} \mathrm{CNMR}_{(\mathrm{CD}} \mathrm{OD}$, $100 \mathrm{MHz}$ ) $\delta_{\mathrm{C}} 175.72,174.78,173.69$ (CONH, amide), 159.55, 159.04, 158.04 (CONHBoc, CONBoc $\times 2$, CONHZ $\times 4$ overlapping), 138.62, 138.58, 129.93, 129.37129 .23 (Ar-C, overlapping), 81.14, 80.15, $\left(\mathrm{C}\left(\mathrm{CH}_{3}\right)_{3} \times 3\right.$, overlapping), 67.96, 67.91, $67.47\left(\mathrm{Ar}-\mathrm{CH}_{2}\right.$, 
overlapping), 55.85, $55.77(\mathrm{COCH}(\mathrm{R}) \mathrm{NH} \times 3$, overlapping), 46.56, 46.37, 41.39, 39.93, 32.86, 32.52, 32.34, $30.42\left(\mathrm{CH}_{2} \mathrm{~N}\right.$, overlapping), $28.74\left(\left(\mathrm{CH}_{3}\right)_{3} \mathrm{C} \times 9\right.$, overlapping), 27.64, 25.41, $23.93\left(\mathrm{CH}_{2} \mathrm{CH}_{2} \mathrm{~N}\right.$, overlapping); $\underline{\mathbb{R}}(\mathrm{KBr} \operatorname{disc}) v_{\max } \mathrm{Cm}^{-1} 3441,3330(\mathrm{NH}), 1638(\mathrm{C}=0)$, 1600, 1580 (aromatic), 1553 (CONH, amide 2), 1509, 1251 (OCONH, carbamate); ESI-MS $(\mathrm{m} / \mathrm{z})$ calculated value for $\mathrm{C}_{75} \mathrm{H}_{110} \mathrm{~N}_{10} \mathrm{O}_{17} \mathrm{Na} 1445.8$ (100.0\%), $1446.8(83.0 \%), 1447.8$ (40.6\%): (ES+) found 1445.5 (100\%), 1446.6 (70.0\%), 1447.8 (30.0\%); $R_{\mathrm{f}} 0.37$ (90: 10 DCM$\underline{\mathrm{MeOH}}$ ninhydrin stain); m.p.: $138-140^{\circ} \mathrm{C} ;[\alpha]^{293} \mathrm{D}-9.4\left(c=1.0, \mathrm{CH}_{3} \mathrm{OH}\right)$.

Compound 5. Compound Z-5 (2.0 g, $1.40 \mathrm{mmol}, 1$ eq.), ammonium formate $(0.53 \mathrm{~g}, 8.4$ mmol, 6 eq.) and palladium hydroxide on carbon ( $20 \mathrm{wt} \%$, wet) $(0.90 \mathrm{~g}, 0.71 \mathrm{mmol}, 0.5$ eq.) were refluxed in ethanol $(100 \mathrm{~mL})$ for $48 \mathrm{~h}$. The mixture was allowed to cool to room temperature and filtered over celite to remove the solids, and the solvents were removed on a rotary evaporator. The mixture was dissolved in $\underline{\mathrm{DCM}}(50 \mathrm{~mL})$, washed with conc. $\mathrm{NH}_{4} \mathrm{OH}$ and brine, dried over $\mathrm{MgSO}_{4}$, and the solvents removed on a rotary evaporator. $\mathrm{A}$ hygroscopic waxy orange solid was recovered (1.02 g, 82\%). ${ }^{1} \mathrm{H} \mathrm{NMR}\left(\mathrm{CD}_{3} \mathrm{OD}, 400 \mathrm{MHz}\right) \delta_{\mathrm{H}}$ 7.80-7.73 (2H, br m, NH amide $\mathrm{G} 2), 6.71-6.69(1 \mathrm{H}, b r \mathrm{~m}, \mathrm{NH}$ amide $\mathrm{G} 1), 6.31-6.23(1 \mathrm{H}, b r$ m, NHBOC), 4.70-4.50 (8H, br m, NH $\mathrm{N}_{2}$, 4.29-4.04 (3H, br m, $\mathrm{COCH}(\mathrm{R}) \mathrm{NH}$, overlapping), 3.28-3.14 $\left(12 \mathrm{H}\right.$, br m, $\left.\mathrm{CH}_{2} \mathrm{~N}\right), 3.01\left(2 \mathrm{H}, \mathrm{t}, J=6.5 \mathrm{~Hz}, \mathrm{CH}_{2} \mathrm{NH}\right), 2.65(4 \mathrm{H}, \mathrm{t}, J=7.3 \mathrm{~Hz}$, $\left.\mathrm{CH}_{2} \mathrm{NH}_{2}\right), 1.86-1.04\left(53 \mathrm{H}\right.$, br m, $\left.\mathrm{CH}_{2}, \mathrm{CH}_{3}\right) ;{ }^{13} \mathrm{C} \mathrm{NMR}\left(\mathrm{CD}_{3} \mathrm{OD}, 100 \mathrm{MHz}\right) \delta_{\mathrm{C}} 175.73,174.88$, 173.64 (CONH, amide), 159.55, 159.03 (CONBoc $\times 2$ 2, CONHBoc, overlapping), 80.95, 80.91,

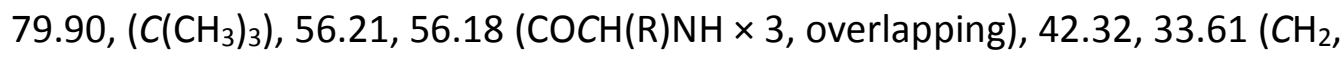
overlapping), $28.81\left(\left(\mathrm{CH}_{3}\right)_{3} \mathrm{CO} \times 9\right.$, overlapping), 29.53, 27.64, 25.41, $23.93\left(\mathrm{CH}_{2} \mathrm{CH}_{2} \mathrm{~N}\right.$, overlapping); IR ( $\mathrm{KBr}$ disc) $v_{\max } \mathrm{cm}^{-1} 3431,3330(\mathrm{NH}), 1639(\mathrm{C}=0), 1553$ (CONH, amide 2), 1509, 1251 (OCONH carbamate); ESI-MS $\left(\mathrm{m} / \mathrm{z}\right.$ ) calculated value for $\mathrm{C}_{43} \mathrm{H}_{86} \mathrm{~N}_{10} \mathrm{O}_{9}$ 887: (ES ${ }^{+}$) found $910\left([\mathrm{M}+\mathrm{Na}]^{+}, 100 \%\right) ;[\alpha]^{293}-20.7\left(c=1.0, \mathrm{CH}_{3} \mathrm{OH}\right)$.

Compound G2-Boc. Compound 5 (0.35 g, 0.4 mmol, 1 eq.) and acid 2 ( 0.36 g, 0.3 mL, 2 mmol, 5 eq.) were dissolved in DCM $(50 \mathrm{~mL})$. DCC (0.41 g, 2 mmol, 5 eq.), HOBt $(0.27 \mathrm{~g}, 2$ mmol, 5 eq.) and $\mathrm{Et}_{3} \mathrm{~N}(0.2 \mathrm{~g}, 2 \mathrm{mmol}, 5$ eq.) were added and the mixture was placed in an ice bath for $1 \mathrm{~h}$ and then left to stir at $\mathrm{rt}$ for $2 \mathrm{~d}$. Dicyclohexylurea (DCU) was removed by filtration, and the solvents removed by rotary evaporation. The crude product was purified initially by preparative gel permeation chromatography ( $\underline{\mathrm{MeOH}}$, Sephadex), and subsequently by silica column chromatography $(90: 10, \underline{\mathrm{DCM}}-\underline{\mathrm{MeOH}})$, a clear oil was 
recovered (0.44 g, $0.29 \mathrm{mmol}, 73 \%) .{ }^{1} \mathrm{H}$ NMR $\left(\mathrm{CD}_{3} \mathrm{OD}, 400 \mathrm{MHz}\right) \delta_{\mathrm{H}} 8.12-7.81(6 \mathrm{H}, \mathrm{br} \mathrm{m}$, $\mathrm{NH}$ amide), 7.06-7.02 (1H, br m, NH amide), 6.55-6.36 (1H, br m, NHBOC), 4.35 (1H, dd, J $=5.6,8.7 \mathrm{~Hz}, \mathrm{COCH}(\mathrm{R}) \mathrm{NH}), 4.27(1 \mathrm{H}, \mathrm{dd}, J=5.2,9.1 \mathrm{~Hz}, \mathrm{COCH}(\mathrm{R}) \mathrm{NH}), 4.16(1 \mathrm{H}, \mathrm{dd}, J=5.2$, $9.1 \mathrm{~Hz}, \mathrm{COCH}(\mathrm{R}) \mathrm{NH}), 4.01-3.80\left(8 \mathrm{H}, \mathrm{br} \mathrm{m}, \mathrm{OCH}_{2} \mathrm{CONH}\right), 3.80-3.40\left(32 \mathrm{H}, b r \mathrm{~m}, \mathrm{OCH}_{2}\right), 3.35-$ $3.30\left(12 \mathrm{H}\right.$, br s, $\left.\mathrm{OCH}_{3}\right), 3.28-3.14\left(14 \mathrm{H}, b r \mathrm{~m}, \mathrm{CH}_{2} \mathrm{~N}\right), 3.13-3.09\left(2 \mathrm{H}, \mathrm{t}, \mathrm{J}=6.6 \mathrm{~Hz}, \mathrm{CH}_{2} \mathrm{NH}\right)$, $3.01\left(2 \mathrm{H}, \mathrm{t}, J=7.3 \mathrm{~Hz}, \mathrm{CH}_{2} \mathrm{NH}\right), 1.71-1.16\left(53 \mathrm{H}, \mathrm{br} \mathrm{m}, \mathrm{CH}_{2}, \mathrm{CH}_{3}\right) . \underline{{ }^{13} \mathrm{C} \mathrm{NMR}}\left(\mathrm{CD}_{3} \mathrm{OD}, 100\right.$ $\mathrm{MHz}) \delta_{\mathrm{C}} 173.62,172.59,172.54$ (CONH $\times 7$, amides, overlapping), 159.32, 157.87 (CONBoc

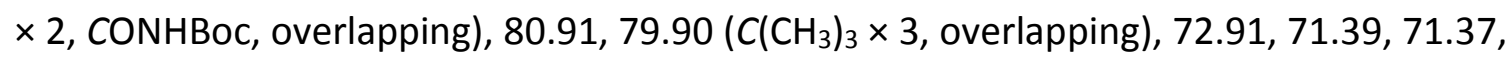
$71.34\left(\mathrm{CH}_{2} \mathrm{O}\right.$, overlapping), $59.17\left(\mathrm{OCH}_{3}\right), 55.25,55.02$ ( $\mathrm{COCH}(\mathrm{R}) \mathrm{NH}$, overlapping), 46.58, $46.37,41.83,40.65,39.68,39.65,38.23,37.61,37.30,30.13\left(\mathrm{CH}_{2}\right.$, overlapping), 28.81 $\left(\left(\mathrm{CH}_{3}\right)_{3} \mathrm{C} \times 9\right.$, overlapping), $24.31\left(\mathrm{CH}_{2} \mathrm{CH}_{2} \mathrm{~N}\right.$, overlapping); $\underline{\mathrm{R}}(\mathrm{KBr} \operatorname{disc}) v_{\max } \mathrm{cm}^{-1} 3444,3341$ (NH), 1659 ( $\mathrm{C}=\mathrm{O}), 1538$ (CONH, amide 2), 1509 (CONH, carbamate), 1366 (O- $\mathrm{CH}_{3}$, ether), 1250 (OCONH, carbamate); ESI-MS $(\mathrm{m} / z)$ calculated value for $\mathrm{C}_{71} \mathrm{H}_{134} \mathrm{~N}_{10} \mathrm{O}_{25} \mathrm{Na} 1549.9$ (100.0\%), 1550.9 (79.3\%), 1551.9 (36.2\%): (ES+) found 1549.7 (100.0\%), 1550.7 (71.8\%), $1551.8(30.6 \%)$; also found $\left[\mathrm{C}_{71} \mathrm{H}_{134} \mathrm{~N}_{10} \mathrm{O}_{25} \mathrm{Na}_{2}\right]^{2+}$, with peaks at $786.2\left(15.1 \%\right.$ of the $\left.\mathrm{M}^{+}\right)$, and others at $786.7\left(77 \%\right.$ of the $\left.\mathrm{M}^{2+}\right), 787.2\left(38 \%\right.$ of the $\left.\mathrm{M}^{2+}\right) ; R_{\mathrm{f}} 0.25(90: 10 \underline{\mathrm{DCM}}-\underline{\mathrm{MeOH}}$, ninhydrin stain); $[\alpha]^{293}-9.2\left(c=1.0, \mathrm{CH}_{3} \mathrm{OH}\right)$.

Anion receptor G2. Compound G2-Boc (0.196 g, $0.79 \mathrm{mmol})$ was dissolved in $\mathrm{MeOH}$ (150 $\mathrm{mL}$ ) and gaseous hydrogen chloride was bubbled through for 30 seconds. The reaction was allowed to stir for $2 \mathrm{~h}$, after which time the solvent was removed under reduced pressure, and a white solid was recovered $(0.170 \mathrm{~g}, 0.79 \mathrm{mmol}, 100 \%)$. Yield calculated for $\mathrm{HCl}$ salt, FW: $1336 . \underline{{ }^{1} \mathrm{H} \mathrm{NMR}}\left(\mathrm{CD}_{3} \mathrm{OD}, 400 \mathrm{MHz}\right) \delta_{\mathrm{H}} 8.14-7.80(6 \mathrm{H}, \mathrm{br} \mathrm{m}, \mathrm{NH}$ amide $), 7.06-7.02(1 \mathrm{H}$, br m, NH), $4.35(1 \mathrm{H}, \mathrm{dd}, J=5.6,8.7 \mathrm{~Hz}, \mathrm{COCH}(\mathrm{R}) \mathrm{NH}), 4.27(1 \mathrm{H}, \mathrm{dd}, J=5.2,9.1 \mathrm{~Hz}$, $\mathrm{COCH}(\mathrm{R}) \mathrm{NH}), 4.16(1 \mathrm{H}, \mathrm{dd}, J=5.2,9.1 \mathrm{~Hz}, \mathrm{COCH}(\mathrm{R}) \mathrm{NH}), 4.10-3.80\left(8 \mathrm{H}, b r \mathrm{~m}, \mathrm{OCH}_{2} \mathrm{CONH}\right)$, 3.80-3.40 (32H, br m, OCH $), 3.35-3.29\left(12 \mathrm{H}, b r \mathrm{~s}, \mathrm{OCH}_{3}\right), 3.28-3.14\left(10 \mathrm{H}, b r \mathrm{~m}, \mathrm{CH}_{2} \mathrm{~N}\right)$, 3.13-2.95 (4H, br m, CH $\left.\mathrm{CH}_{2} \mathrm{NH}, 8 \mathrm{H}\right), 2.11-1.14\left(26 \mathrm{H}\right.$, br m, $\left.\mathrm{CH}_{2}\right) ;{ }^{13} \mathrm{C} \mathrm{NMR}\left(\mathrm{CD}_{3} \mathrm{OD}, 100 \mathrm{MHz}\right)$ $\delta_{\mathrm{C}} 173.63,172.59,172.53$ (CONH $\times 7$, amides, overlapping), 72.65, 71.72, 71.37, 71.11 $\left(\mathrm{CH}_{2} \mathrm{O}\right.$, overlapping), $58.94\left(\mathrm{OCH}_{3}\right), 55.23,54.99$ ( $\mathrm{COCH}(\mathrm{R}) \mathrm{NH}$, overlapping), 39.34, 37.61, $37.35,32.03,30.87,29.7828 .38,24.50,24.45\left(\mathrm{CH}_{2}\right.$, overlapping); IR ( $\left.\mathrm{KBr} \operatorname{disc}\right) v_{\max } \mathrm{cm}^{-1}$ 3444, $3336(\mathrm{NH}), 1641(\mathrm{C}=\mathrm{O}), 1602\left(\mathrm{NH}_{2}{ }^{+}, \mathrm{NH}_{3}{ }^{+}\right), 1553(\mathrm{CONH}$, amide 2$), 1366\left(\mathrm{O}-\mathrm{CH}_{3}\right.$, ether); ESI-MS $(m / z)$ calculated value for $\mathrm{C}_{56} \mathrm{H}_{110} \mathrm{~N}_{10} \mathrm{O}_{19} \mathrm{Na} 1249.8$ (100.0\%), 1250.8 
(62.6\%), 1251.8 (25.4\%): (ES+) found 1249.8 (100.0\%), 1250.8 (65.5\%), 1251.8 (20.5\%); also found $\left[\mathrm{C}_{56} \mathrm{H}_{110} \mathrm{~N}_{10} \mathrm{O}_{19} \mathrm{Na}_{2}\right]^{2+}$, with a peak at 637.0 (10\% of the intensity of the $\mathrm{M}^{+}$ion). $[\alpha]^{293}{ }_{D}-2.34\left(c=1.0, \mathrm{CH}_{3} \mathrm{OH}\right)$.

\section{Acknowledgements}

We acknowledge EPSRC and Syngenta for funding the research.

\section{References}

1. (a) D. A. Tomalia, Prog. Polym. Sci., 2005, 30, 294-324 (b) G. R. Newkome, C. N. Moorefield and F. Vögtle, Dendrimers and Dendrons: Concepts, Syntheses, Applications, Wiley-VCH, Weinheim, 2001.

2. (a) D. K. Smith and F. Diederich, Top. Curr. Chem., 2000, 210, 183-227 ; (b) D. K. Smith, A. R. Hirst, C. S. Love, J. G. Hardy, S. V. Brignell and B. Huang, Prog. Polym. Sci., 2005, 30, 220-293 ; (c) P. J. Gittins and L. J. Twyman, Supramol. Chem., 2003, 15, 5-23; (d) S. C. Zimmerman and L. J. Lawless, Top. Curr. Chem., 2001, 217, 95120 .

3. A. Mulder, J. Huskens and D. N. Reinhoudt, Org. Biomol. Chem., 2004, 2, 34093424.

4. See for example: (a) D. K. Smith, A. Zingg and F. Diederich, Helv. Chim. Acta, 1999, 82, 1225-1241; (b) J. P. Collman, L. Fu, A. Zingg and F. Diederich, Chem. Commun., 1997, 193-194 .

5. (a) D. K. Smith and F. Diederich, Chem.-Eur. J., 1998, 4, 1353-1361 ; (b) J. Kofoed and J. L. Reymond, Curr. Opin. Chem. Biol., 2005, 9, 656-664 .

6. (a) K. Bowman-James, Acc. Chem. Res., 2005, 38, 671-678 ; (b) P. A. Gale, Coord. Chem. Rev., 2003, 240, 1 and articles therein.

7. V. Arnendola, M. Bonizzoni, D. Esteban-Gomez, L. Fabbrizzi and M. Licchelli, Coord. Chem. Rev., 2006, 250, 1451-1470.

8. J. M. Llinares, D. Powell and K. Bowman-James, Coord. Chem. Rev., 2003, 240, 5775. 
9. (a) C. Valério, J.-L. Fillaut, J. Ruiz, J. Guittard, J.-C. Blais and D. Astruc, J. Am. Chem. Soc., 1997, 119, 2588-2589 (b) M. C. Daniel, J. Ruiz, S. Nate, J.-C. Blais and D. Astruc, J. Am. Chem. Soc., 2003, 125, 2617-2628 ; (c) J. R. Aranzaes, C. Belin and D. Astruc, Angew. Chem., Int. Ed., 2006, 45, 132-136; (d) B. Alonso, C. M. Casado, I. Cuadrado, M. Moran and A. E. Kaifer, Chem. Commun., 2002, 1778-1779 .

10. D. L. Stone and D. K. Smith, Polyhedron, 2003, 22, 763-768 .

11. H. Stephan, H. Spies, B. Johannsen, L. Klein and F. Vögtle, Chem. Commun., 1999, 1875-1876.

12. (a) A. W. Kleij, R. van der Coevering, R. J. M. K. Gebbink, A. M. Noordman, A. L. Spek and G. van Koten, Chem.-Eur. J., 2001, 7, 181-192; (b) F. Marchioni, M. Venturi, A. Credi, V. Balzani, M. Belohradsky, A. M. Elizarov, H. R. Tseng and J. F. Stoddart, J. Am. Chem. Soc., 2004, 126, 568-573;(c) R. van der Coevering, R. Kreiter, F. Cardinali, G. van Koten and J. F. Nierengarten, Tetrahedron Lett., 2005, 46, 3353-3356.

13. S. Onclin, J. Huskens, B. J. Ravoo and D. N. Reinhoudt, Small, 2005, 1, 852-857 and references therein.

14. D. K. Smith, Chem. Commun., 2006, 34-44.

15. (a) M. A. Kostiainen, J. G. Hardy and D. K. Smith, Angew. Chem., Int. Ed., 2005, 44, 2556-2559 ; (b) J. G. Hardy, M. A. Kostiainen, D. K. Smith, N. P. Gabrielson and D. W. Pack, Bioconjugate Chem., 2006, 17, 172-178 ; (c) M. A. Kostiainen, G. R. Szilvay, D. K. Smith, M. B. Linder and O. Ikkala, Angew. Chem., Int. Ed., 2006, 45, $3538-3542$

16. (a) C. W. Tabor and H. Tabor, Annu. Rev. Biochem., 1984, 740-790 ; (b) V. Vijayanathan, T. Thomas, A. Shirahata and T. J. Thomas, Biochemistry, 2001, 40, 13644-13651

17. I. S. Blagbrough and A. J. Geall, Tetrahedron Lett., 1998, 39, 439-442

18. R. G. Gonzalez, R. S. Haxo and T. Schleich, Biochemistry, 1980, 19, 4299-4304

19. (a) D. K. Smith, Chem. Commun., 1999, 1685-1686; (b) G. M. Dykes, L. J. Brierley, D. K. Smith, P. T. McGrail and G. J. Seeley, Chem.-Eur. J., 2001, 7, 4730-4739

20. G. M. Dykes, D. K. Smith and A. Caragheorgheopol, Org. Biomol. Chem., 2004, 2, 922-926 
21. C. Nakai and W. Glinsmann, Biochemistry, 1977, 16, 5636-5641

22. (a) S. I. Watanabe, K. Kusama-Eguchi, H. Kobayashi and K. Igarashi, J. Biol. Chem., 1991, 266, 20803-20809 ; (b) D. Meksuriyen, T. Fukuchi-Shimogori, H. Tomitori, K. Kashiwagi, T. Toida, T. Imanari, G. Kawai and K. Igarashi, J. Biol. Chem., 1998, 273, 30939-30944.

23. (a) C. J. Hawker, K. L. Wooley and J. M. J. Fréchet, J. Am. Chem. Soc., 1993, 115, 4375-4376 ; (b) P. Weyermann, F. Diederich, J.-P. Gisselbrecht, C. Boudon and M. Gross, Helv. Chim. Acta, 2002, 85, 571-598 ; (c) T. L. Chasse, R. Sachveda, C. Li, Z. M. Li, R. J. Petrie and C. B. Gorman, J. Am. Chem. Soc., 2003, 125, 8250-8254; (d) D. L. Stone, D. K. Smith and P. T. McGrail, J. Am. Chem. Soc., 2002, 124, 856-864; (e) S. Koenig, L. Müller and D. K. Smith, Chem.-Eur. J., 2001, 7, 979-986 